\title{
POLA PENGEMBANGAN PENDIDIKAN DAN BUDAYA KARAKTER BANGSA DI SEKOLAH, MADRASAH DAN PESANTREN
}

\section{Patterns of Education and Culture Development of the Nation's Character in School, Madrasah, and Islamic Boarding School}

\author{
Basuki \\ Institut Agama Islam Negeri Ponorogo \\ E-mail: basukinet344@gmail.com
}

DOI: $10.53754 /$ edusia.v1i1.22

\begin{tabular}{l|l|l}
\hline Received: 2021-07-17 & Revised: 2021-07-22 & Approved: 2021-07-25 \\
\hline
\end{tabular}

\begin{abstract}
Education-based on character and culture is urgent to be developed in Indonesia to maintain the integrity of the Indonesian nation in the future. This development must be carried out jointly by elements of educational institutions. In Indonesia, three educational institutions can develop the fundamental values of character education, namely pesantren, madrasah, and schools. This research using a qualitative approach has revealed national character education and culture in Islamic Boarding Schools, Madrasah, and Schools, namely at the Brotonegaran 2 Ponorogo State Elementary School Ibtidaiyah Madrasah Mayak Ponorogo and Darul Falah Islamic Boarding School Sukorejo Ponorogo. The research found two suggestions that need to be considered by pesantren, madrasah and schools, namely the development of character education and national culture should be carried out sustainably and does not need to be taught but developed habituation and example.
\end{abstract}

Keywords: Character; culture; Islamic Boarding School; Madrasah; School

\begin{abstract}
Abstrak: Pendidikan yang berbasis karakter dan budaya urgen untuk di kembangkan di indonesia untuk menjaga keutuhan bangsa Indonesia di masa yang akan datang. Pengembangan itu harus dilakukan harus dilakukan secara bersama oleh elemen lembaga pendidikan. Di Indonesia ada tiga elemen lembaga pendidikan yang bisa di gunakan untuk pengembangan nilai dasar pendidikan karakter, yaitu pesantren, madrasah dan sekolah. Dengan menggunakan pendekatan kualitatif penelitian ini telah mengungkap pola pengembangan pendidikan dan budaya karakter bangsa di Pesantren, Madrasah dan Sekolah, yaitu di Sekolah Dasar Negeri Brotonegaran 2 Ponorogo, Madrasah Ibtidaiyah Mayak Ponorogo dan Pesantren Darul Falah Sukorejo Ponorogo. Dari penelitian ditemukan dua saran yang perlu diperhatikan oleh pihak pesantren, madrasah dan sekolah, yaitu pengembangan pendidikan karakter dan budaya bangsa sebaiknya dilaksanakan secara berkelanjutan dan tidak perlu diajarkan tetapi dikembangkan dengan cara pembiasaan dan keteladanan.
\end{abstract}

Kata Kunci: Budaya; karakter; Pesantren, Madrasah, Sekolah

\section{PENDAHULUAN}

Isu budaya dan identitas bangsa kembali mengemuka di mata publik. Fokusnya adalah pada berbagai segi kehidupan, seperti yang diungkapkan melalui berbagai tulisan di media cetak, serta wawancara, dialog, dan pidato di media elektronik. Selain media massa, tokoh masyarakat, pakar pendidikan, dan pemerhati sosial membahas isu budaya dan jati diri bangsa dalam berbagai forum ilmiah di beberapa tingkatan. 
Di samping itu di dukung dengan adanya regulasi yang mendukungnya, tema pendidikan karakter ini selalu hangat di perbincangkan karena segala sesuatu selalu didasari dengan moral, seperti halnya pada media masa dan pemberitaan di televisi yang selalu hangat membicarakan kriminalitas, korupsi, tawuran, politik tidak sehat dll, semua perilaku tersebut karena kurangnya moral pada diri pelaku.

Promosi pendidikan budaya dan pengembangan karakter bangsa juga sering di advokasi sebagai cara untuk mengatasi atau mengurangi masalah ini. Atas dasar ini, pengembangan pendidikan budaya dan karakter sangat penting bagi kelangsungan dan keunggulan negara dalam jangka panjang di masa depan. Pengembangan ini harus dilakukan melalui perencanaan yang matang, pendekatan yang tepat, dan penggunaan metode pembelajaran dan pembelajaran yang efektif. Pendidikan budaya dan pendidikan nasional merupakan upaya bersama sekolah yang harus dilaksanakan secara kolaboratif oleh seluruh guru dan pimpinan sekolah di segala bidang agar menjadi bagian yang tidak terpisahkan dari budaya sekolah. Hal ini sesuai dengan hakikat nilai dan harus dilaksanakan oleh seluruh guru dan pimpinan sekolah di segala bidang agar menjadi bagian yang tidak terpisahkan dari budaya sekolah.

Banyak akademisi yang belum melakukan penelitian tentang pengembangan pendidikan budaya dan karakter bangsa secara holistik komparatif yang berujung pada ditemukannya pola pengembangan budaya dan karakter bangsa. Penelitian mereka hanyalah salah satu fokus penelitian. ${ }^{1}$ Temuan ini hanya mengkaji bagaimana internalisasi nilai-nilai pendidikan dan karakter bangsa melalui budaya sekolah, melalui pengembangan diri dan pembelajaran di kelas, tidak dibandingkan dengan temuan. Karena karakter seseorang bersifat holistik.

Tulisan berikut mengungkapkan bagaimana SD Negeri Brotonegaran 2 Ponorogo, Madrasah Ibtidaiyah Mayak Ponorogo, dan Pondok Pesantren Darul Falah Sukorejo Ponorogo mengembangkan budaya dan strategi untuk melatih karakter bangsa sesuai dengan pemikiran di atas. Bagaimana pola pengembangan pendidikan budaya dan karakter di SD Negeri Brotonegaran 2 Ponorogo, MI Ma'arif Mayak Ponorogo, dan Pesantren Darul Falah Sukorejo Ponorogo?

Tujuan penelitian ini adalah mendeskripsikan pola pengembangan pendidikan budaya dan karakter bangsa di SD Negeri Brotonegaran 2 Ponorogo, MI Ma'arif Mayak Ponorogo, dan Pesantren Darul Falah Sukorejo Ponorogo, serta di SD Negeri Brotonegaran 3 Ponorogo.

Metode penelitian kualitatif yang digunakan dalam penelitian ini Bogdan dan Taylor mendefinisikan "pendekatan kualitatif" sebagai metode penelitian yang mengumpulkan data deskriptif dari orang-orang dan mengamati perilaku

1 Salahudin Wahid, "PENDIDIKAN KARAKTER BERBASIS PESANTREN," TARBAWI 3, no. 1 (2018), https://doi.org/10.36781/tarbawi.v3i1.2961. 
(tindakan). ${ }^{2}$ Penelitian kualitatif berbeda dari jenis penelitian lainnya dalam beberapa hal. Bogdan dan Biklen mengidentifikasi lima karakteristik penelitian kualitatif: naturalistik, deskriptif, proses, induktif, dan makna. ${ }^{3}$ Menurut Lincoln dan Guba, penelitian kualitatif lebih mementingkan proses daripada hasil. ${ }^{4}$

Ini adalah deskripsi singkat tentang bagaimana kelima sifat tersebut digunakan dalam penelitian ini. Pertama, penelitian kualitatif dan pada setting alam dan peneliti sebagai instrumen kunci. Oleh karena itu peneliti turun ke lapangan (tidak terwakili) untuk mewawancarai warga SD Negeri Brotonegaran 2 Ponorogo, MI. Pesantren Sukorejo Ponorogo “Darul Falah”. Ini juga deskriptif. Data disajikan dalam kata-kata, gambar, dan bukan angka. Data yang diambil dari laporan penelitian berfungsi sebagai ilustrasi dan dukungan faktual. Transkrip wawancara, catatan lapangan, foto, dokumen, dan rekaman lainnya disertakan. Ketiga, proses mengalahkan hasil dalam penelitian kualitatif. Keempat, analisis dalam penelitian kualitatif cenderung induktif. Penelitian ini diawali dengan data lapangan, kemudian menggunakan teori untuk menjelaskan data tersebut, dan diakhiri dengan penemuan suatu hipotesis atau teori. 5 Makna sangat penting dalam penelitian kualitatif. Menurut penelitian ini, "kegiatan warga sekolah/madrasah" memiliki "makna". Pesan tentang pendidikan budaya dan karakter bangsa.

Desain penelitian yang digunakan dalam penelitian ini adalah studi multi kasus, yaitu desain penelitian kualitatif yang digunakan untuk beberapa kasus/tempat atau subjek penelitian dengan situasi sosial yang bervariasi. $^{5}$

Penelitian kualitatif tidak dapat dipisahkan dari observasi partisipan, karena peneliti menetapkan skenario keseluruhan. Akibatnya, peran peneliti dalam penelitian ini adalah sebagai instrumen kunci, partisipan penuh, dan pengumpul data. Sedangkan instrumen yang tersisa berfungsi sebagai cadangan. ${ }^{6}$

Dalam penelitian kualitatif, sumber data primer adalah kata-kata dan tindakan; selebihnya merupakan sumber pelengkap seperti dokumen dan lain-lain. Dalam hal ini, wawancara, observasi, dan dokumentasi digunakan sebagai teknik pengumpulan data. ${ }^{7}$

2 Helen Brooks, Penny Bee, and Anne Rogers, "Introduction to Qualitative Research Methods," in A Research Handbook for Patient and Public Involvement Researchers, 2019, https:/ / doi.org/10.7765/9781526136527.00012.

${ }^{3}$ Robert C. Bogdan and Sari Knopp Biklen, "Characteristics of Qualitative Research," in Qualitative Research for Education: An Introduction to Theory and Methods, 2003.

${ }^{4}$ Michael Q. Patton, Egon G. Guba, and Yvonna S. Lincoln, "Effective Evaluation: Improving the Usefulness of Evaluation Results Through Responsive and Naturalistic Approaches," The Journal of Higher Education 54, no. 3 (1983), https:// doi.org/10.2307/1981810.

5 Bogdan and Biklen, "Characteristics of Qualitative Research."

${ }^{6}$ Participate in research that is characterized by social interactions that take a long time between researchers and subjects in the subject's environment, and as long as data in the form of field notes are collected systematically and the notes are valid without interruption Bogdan and Biklen.

7 John Lofland et al., "Analyzing Social Settings: A Guide to Qualitative Observation and Analysis (4th Ed.)," Analyzing Social Settings: A Guide to Qualitative Observation and Analysis (4th Ed.), 2006. 
Analisis data adalah pencarian sistematis dan kompilasi data yang diperoleh dari wawancara, catatan lapangan, dan sumber lain agar mudah diakses dan temuannya dikomunikasikan kepada orang lain. Analisis data dilakukan dengan mengorganisasikan data, menguraikannya menjadi unit-unit, mensintesiskannya, menyusunnya dalam suatu pola, menentukan apa yang signifikan dan apa yang akan dipelajari, dan menarik kesimpulan yang dapat dikomunikasikan kepada orang lain. ${ }^{8}$ Analisis data dalam penelitian ini berlangsung dalam dua tahap: analisis satu kasus dan analisis lintas kasus.

Satu situasi sosial merupakan salah satu lokasi penelitian. Konsep analisis data kualitatif Miles \& Huberman mengemukakan bahwa kegiatan dalam analisis data kualitatif dilakukan secara interaktif dan berkesinambungan pada setiap tahapan penelitian sampai datanya jenuh. Reduksi data, penyajian data, dan penarikan kesimpulan semuanya terlibat. ${ }^{9}$

Data yang dikumpulkan dari wawancara, observasi, dan dokumentasi pada ketiga anggota masyarakat tersebut bersifat kompleks. Akibatnya, peneliti mereduksi data dengan meringkas kegiatan utama, memilih hal-hal penting, dan fokus pada mereka.

Data yang direduksi akan memberikan gambaran yang lebih jelas, dan peneliti akan mempermudah pengumpulan data di masa mendatang. Setelah reduksi data, langkah selanjutnya adalah display data, yaitu penyajian data dalam bentuk deskripsi dan bagan yang menghubungkan kategori-kategori. Terakhir, kesimpulan dan verifikasi.

\section{PEMBAHASAN}

\subsection{Literature Review}

\subsubsection{Tujuan Pendidikan Nasional dan Pendidikan Karakter}

Undang-Undang Sistem Pendidikan Nasional menetapkan fungsi dan tujuan pendidikan nasional dan menjadi landasan bagi kegiatan pendidikan di Indonesia. Menurut Pasal 3 UU Sisdiknas, "Pendidikan nasional berfungsi mengembangkan dan membentuk watak serta peradaban bangsa yang bermartabat dalam rangka mencerdaskan kehidupan bangsa". berakhlak mulia, sehat, berilmu, cakap, kreatif, mandiri. ${ }^{10}$ Tujuan pendidikan nasional adalah untuk mengembangkan definisi

\footnotetext{
8 Analysis is a process that allows you to systematically search and arrange the transcripts, field notes and other materials you collect for your own understanding of and to present to others what you have found. Bogdan and Biklen, "Characteristics of Qualitative Research."

${ }^{9}$ Matthew B Miles and Michael A. Huberman, Analisis Data Kualitatif: Buku Sumber Tentang Metode-Metode Baru, UI Press, 2012.

10 Kementerian Pendidikan Nasional, UU Nomor 20 Tahun 2003 tentang Sistem Pendidikan Nasional, Undang-Undang Republik Indonesia Nomor 20 Tahun 2003 Tentang Sistem Pendidikan Nasional Dengan Rahmat Tuhan Yang Maha Esa Presiden Republik Indonesia, issued 2003.
} 
kualitas manusia Indonesia yang harus dikembangkan oleh setiap satuan pendidikan. Dengan demikian, rumusan tujuan pendidikan nasional menjadi landasan bagi tumbuhnya pendidikan budaya dan karakter bangsa. Untuk mengetahui pengertian pendidikan budaya dan karakter bangsa, maka perlu didefinisikan istilah budaya, ${ }^{11}$ karakter bangsa ${ }^{12}$, dan pendidikan. ${ }^{13}$

Pengembangan pendidikan budaya dan karakter sangat penting bagi keberlanjutan dan keunggulan bangsa di masa depan. Pertumbuhan ini harus terjadi sebagai hasil dari perencanaan yang matang, pendekatan yang tepat, dan metode pembelajaran dan pembelajaran yang efektif. Pendidikan budaya dan karakter bangsa, pada hakikatnya, merupakan upaya kolaboratif dari pihak sekolah; Oleh karena itu, mereka harus dilaksanakan secara kolaboratif oleh semua guru dan kepala sekolah, di semua mata pelajaran, dan menjadi bagian yang tidak terpisahkan dari budaya sekolah.

\subsubsection{Fungsi dan Tujuan Pendidikan Budaya dan Karakter Bangsa}

Pendidikan budaya dan identitas nasional melayani berbagai tujuan. Fungsi pertama adalah mengembangkan potensi peserta didik agar menjadi pribadi yang berkelakuan baik, terutama bagi peserta didik yang telah memiliki sikap dan perilaku yang mencerminkan budaya dan karakter bangsa. Kedua, fungsi perbaikan, yaitu memperkuat peran pendidikan nasional dalam mengembangkan potensi peserta didik yang lebih dikenal. Ketiga, fungsi penyaringan adalah menyaring budaya bangsa sendiri dan budaya bangsa lain yang tidak menganut nilai-nilai budaya dan karakter bangsa yang diakui.

Tujuan pendidikan budaya dan karakter nasional selanjutnya adalah (a) mengembangkan hati, kesadaran, dan kapasitas peserta didik sebagai manusia dan warga negara yang memiliki nilai budaya dan karakter bangsa; (b) mengembangkan

11 Budaya didefinisikan sebagai nilai, moral, norma, dan kepercayaan masyarakat. Ini adalah hasil interaksi manusia dengan alam. Ini adalah seperangkat keyakinan dan nilai-nilai yang digunakan dalam masyarakat untuk menciptakan sistem sosial dan ekonomi. Sudah menjadi sifat manusia untuk menciptakan konstruksi mental yang mengatur interaksi kita dengan manusia dan alam lain. Kehidupan manusia mengembangkan sistem sosial, ekonomi, kepercayaan, ilmu pengetahuan, teknologi, dan seni. Melalui pendidikan, siswa memperoleh seperangkat nilai, moral \& keyakinan yang mengamankan masyarakat dan mengembangkan warisan itu untuk kehidupan sekarang dan masa depan. Pendidikan budaya dan karakter Kementerian Pendidikan dan Kebudayaan, “Kementerian Pendidikan Dan Kebudayaan," Http://Kemdikbud.Go.Id/ 1969010819, no. 0281 (2017).

12 Karakter dibentuk oleh kebajikan internal yang diyakini dan digunakan sebagai landasan untuk cara pandang, berpikir, dan bertindak. Kebajikan adalah orang yang bertindak dengan integritas, kepercayaan, dan rasa hormat. Interaksi individu membentuk masyarakat dan bangsa. Kepribadian dengan demikian mengembangkan nasionalisme. Karakter individu masyarakat hanya dapat dikembangkan dalam lingkungan sosial budaya. Dengan kata lain, lingkungan sosial siswa, budaya masyarakat, dan budaya bangsa dapat dikembangkan secara non-diskriminatif. Harus berdasarkan nilai-nilai Pancasila. Artinya menanamkan nilai-nilai Pancasila dalam hati, pikiran, dan tubuh siswa. Kementerian Pendidikan dan Kebudayaan.

13 Potensi siswa dikembangkan melalui pendidikan. Pendidikan juga merupakan upaya masyarakat dan bangsa untuk mempersiapkan generasi penerus bangsa. Kepemilikan masyarakat dan nasional menentukan keberlanjutan. Dengan demikian, pendidikan adalah proses mewariskan karakter bangsa kepada generasi penerus dan mengembangkan budaya dan karakter bangsa. Pendidikan budaya dan karakter bangsa membantu siswa mengembangkan potensinya, menginternalisasi nilai-nilai, dan menghargainya di masyarakat. Kementerian Pendidikan dan Kebudayaan. 
kebiasaan dan perilaku siswa yang sesuai dengan nilai-nilai bangsa. Nilai bangsa. nilai-nilai universal dan tradisi agama budaya, dan c) (martabat).

\subsubsection{Nilai-nilai dalam Pendidikan Budaya dan Karakter Bangsa}

Pendidikan budaya dan karakter bangsa didasarkan pada tiga pilar: agama, Pancasila, dan budaya. Dari ketiga sumber tersebut, satuan pendidikan di Indonesia harus mengembangkan 18 nilai budaya dan karakter bangsa. Tabel berikut merangkum 18 nilai tersebut. ${ }^{14}$

Tabel 1. 18 Nilai dalam Pendidikan Budaya dan Karakter Bangsa

\begin{tabular}{ll}
\hline NILAI & DESKRIPSI \\
\hline 1. Religius & $\begin{array}{l}\text { Agama membutuhkan sikap dan perilaku taat dalam menjalankan } \\
\text { ajarannya, toleransi terhadap pelaksanaan ibadah pemeluk agama lain, } \\
\text { dan hidup rukun dengan pemeluk agama lain. }\end{array}$ \\
\hline 2. Jujur & $\begin{array}{l}\text { Kesopanan yang berpusat pada upaya untuk mempromosikan diri } \\
\text { sebagai orang yang selalu dapat dipercaya dalam perkataan, tindakan } \\
\text { dan pekerjaan. }\end{array}$ \\
\hline 3. Toleransi & $\begin{array}{l}\text { Sikap dan tindakan yang sejalan dengan perbedaan agama, suku, suku, } \\
\text { pendapat, sikap dan tindakan orang lain. }\end{array}$ \\
\hline 4. Disiplin & $\begin{array}{l}\text { Tindakan yang menunjukkan ketertiban dan kesesuaian dengan norma } \\
\text { dan peraturan yang berbeda. }\end{array}$ \\
\hline 5. Kerja Keras & $\begin{array}{l}\text { Perilaku yang menunjukkan upaya tulus untuk mengatasi berbagai } \\
\text { hambatan untuk belajar dan bekerja serta untuk melaksanakan tugas. }\end{array}$
\end{tabular}

\begin{tabular}{ll}
\hline 6. Kreatif & $\begin{array}{l}\text { Berpikir dan melakukan sesuatu yang baru dengan sesuatu yang sudah } \\
\text { Anda miliki. }\end{array}$ \\
\hline 7. Mandiri & sikap dan perilaku yang tidak bergantung pada orang lain. \\
\hline 8. Demokratis & Menilai hak dan kewajiban diri sendiri dan orang lain. \\
\hline 9. Rasa Ingin Tahu & $\begin{array}{l}\text { Sikap dan tindakan yang berusaha untuk belajar lebih dalam dan luas } \\
\text { dari apa yang dipelajari, dilihat, atau didengar. }\end{array}$ \\
\hline 10. Semangat Kebangsaan & $\begin{array}{l}\text { Cara berpikir, bertindak, dan melihat yang mengutamakan } \\
\text { kepentingan bangsa di atas kepentingan pribadi dan golongan. }\end{array}$ \\
\hline 11. Cinta Tanah Air & $\begin{array}{l}\text { Cara seseorang melihat dan bertindak sesuai dengan bahasa bangsanya, } \\
\text { lingkungan fisik, sosial dan budayanya. }\end{array}$ \\
\hline 12. Menghargai Prestasi & $\begin{array}{l}\text { Sikap dan tindakan bercita-cita yang mendorongnya untuk } \\
\text { berkontribusi pada masyarakat dan menghargai kesuksesan orang lain. }\end{array}$ \\
\hline 13. Bersahabat/ Komunikatif & $\begin{array}{l}\text { Berbicara, bersosialisasi, dan bekerja sama dengan orang lain adalah hal } \\
\text { yang menyenangkan. }\end{array}$ \\
\hline 14. Cinta Damai & $\begin{array}{l}\text { Sikap, perkataan, dan tindakan yang membuat orang lain bahagia dan } \\
\text { aman. }\end{array}$ \\
\hline 15. Gemar Membaca & meluangkan waktu untuk membaca bacaan yang bermanfaat \\
\hline 16. Peduli Lingkungan & Sikap dan tindakan dalam mencegah dan memperbaiki kerusakan alam \\
\hline 17. Peduli Sosial & Sikap dan tindakan yang selalu ingin membantu orang lain. \\
\hline
\end{tabular}

14 Kementerian Pendidikan dan Kebudayaan. 


\begin{tabular}{ll}
\hline NILAI & DESKRIPSI \\
\hline 18. Tanggung-jawab & sikap dan perilaku seseorang terhadap dirinya, masyarakat, lingkungan \\
(alam, sosial, dan budaya), negara, dan Tuhan Yang Maha Esa.
\end{tabular}

\subsubsection{Prinsip dan Pendekatan Pengembangan Pendidikan Budaya dan Karakter Bangsa}

Pendidikan dan pengembangan karakter dipandu oleh seperangkat prinsip yang memastikan bahwa siswa mengenali dan menerima nilai-nilai budaya dan karakter negara sebagai milik mereka, membuat keputusan berdasarkan pengetahuan dan sikap, dan menilai pentingnya kepercayaan diri. Peserta memperoleh pengetahuan sebagai hasil dari proses berpikir, siswa, dan pedoman prinsip. Ini adalah tujuan dari proses ketiga untuk membantu siswa meningkatkan kemampuan mereka dalam situasi sosial sementara juga mendorong mereka untuk melihat diri mereka sendiri sebagai makhluk sosial.

Berikut ini adalah prinsip-prinsip dasar yang memandu pengembangan pendidikan budaya dan identitas nasional: ${ }^{15}$

a Sustainable; Hal ini mengandung makna bahwa proses pengembangan nilai budaya dan karakter bangsa merupakan proses yang panjang yang diawali dengan masuknya peserta didik ke dalam satuan pendidikan. Prosesnya dimulai pada tahun pertama atau pertama sekolah dasar dan berakhir paling lambat kelas sembilan atau kelas akhir sekolah menengah pertama, mana yang lebih dulu. Pembinaan budaya dan karakter bangsa di SMA merupakan kelanjutan dari proses sembilan tahun yang dimulai pada tahun 2007.

b Masuk pada setiap mata pelajaran, setiap kurikulum, dan setiap kegiatan ekstrakurikuler wajib diselenggarakan dalam rangka pengembangan nilainilai budaya dan karakter bangsa, dan ini dilakukan melalui semua mata pelajaran, pengembangan diri, dan budaya sekolah.

c Tidak masuk pengajaran tetapi dikembangkan; ini melibatkan materi pelajaran yang normal tentang nilai-nilai budaya dan karakter nasional; Artinya nilainilai tersebut tidak digunakan sebagai bahan diskusi, misalnya dalam pengajaran suatu konsep, teori atau prosedur dalam suatu mata pelajaran seperti agama atau bahasa Indonesia atau pengetahuan atau dalam pengajaran suatu fakta dalam suatu mata pelajaran seperti fisika.

d Proses pendidikan yang diikuti siswa aktif dan menyenangkan. Sebagaimana dinyatakan, siswa bukan guru terlibat dalam proses pembentukan nilai-nilai

15 Kementerian Pendidikan Nasional, UU Nomor 20 Tahun 2003 tentang Sistem Pendidikan Nasional. 
budaya dan karakter bangsa, menurut pernyataan itu. Semua perilaku yang ditunjukkan oleh siswa "tut wuri handayani" dilaksanakan oleh guru. Prinsip lebih lanjut dari prinsip ini adalah bahwa proses pendidikan berlangsung di lingkungan belajar yang menumbuhkan rasa senang daripada indoktrinasi.

\subsection{Pola Pengembangan Pendidikan dan Budaya Karakter Bangsa di Sekolah Dasar Negeri Brotonegaraan 2 Ponorogo}

Pola pertama, SD Negeri Brotonegaraan 2 Ponorogo telah mengembangkan 18 nilai karakter yang telah disepakati oleh kementerian pendidikan nasional.

SD Negeri Brotonegaraan 2 Ponorogo telah menciptakan 18 nilai pendidikan dan budaya nasional sebagai berikut: religius, jujur, toleran, disiplin, kerja keras, kreatif, mandiri, demokratis. Rasa ingin tahu, semangat kebangsaan, cinta tanah air, menghargai prestasi, ramah dan komunikatif.

Pola kedua, SD Negeri Brotonegaraan 2 Ponorogo telah mengembangkan 18 nilai karakter melalui tiga jalur, yaitu mata pelajaran, pengembangan diri dan budaya sekolah SD Negeri Brotonegaraan 2 Ponorogo telah melakukan implementasi nilai-nilai karakter dan budaya bangsa tersebut tidak diajarkan tetapi di-internalisasi-kan dan dikembangkan di sekolah dan di dalam kelas melaui tiga jalur, yaitu kekuatan pembelajaran mata pelajaran, kegiatan pengembangan diri dan kegiatan budaya sekolah.

Dalam konteks kekinian, penguatan pendidikan moral ${ }^{16}$ atau pelatihan karakter ${ }^{17}$ sangat penting dilakukan untuk mengatasi krisis moral yang terjadi di negara kita saat ini. Krisis ini termasuk pergaulan bebas, maraknya kekerasan anak dan teman, kejahatan, perampokan remaja, kecurangan, penggunaan narkoba, pornografi, dan perusakan milik orang lain. Ini bisa menjadi masalah sosial yang belum sepenuhnya terselesaikan.

Krisis yang menimpa siswa (juga elit politik) adalah bahwa pendidikan agama dan moral di sekolah tidak mempengaruhi perubahan perilaku masyarakat Indonesia. Bahkan, yang terlihat adalah ketidaksesuaian antara kata-kata dan

16 Diferensiasi dapat ditemukan antara moralitas, karakter, dan moral. Hal-hal baik dan buruk ada di dunia dan melekat pada setiap orang, dan pengetahuan moral adalah pengetahuan tentang hal-hal ini oleh seseorang. Moral berasal dari istilah latin mores, yang berasal dari suku kata mos dan berarti adat istiadat, tingkah laku, dan kepribadian. Ini adalah konsep yang berbeda untuk berbicara tentang moral. Moralitas diartikan sebagai kualitas pertimbangan baik dan buruk, sedangkan moralitas diartikan sebagai asas baik dan buruk. Pendidikan moral secara sederhana adalah: pendidikan dalam prinsip dan praktik moral. Nilai-nilai yang diajarkan dalam setiap pelajaran atau materi ilmu pengetahuan itulah yang merupakan pendidikan moral. Khuluq (Arab untuk akhlak), yang merupakan bentuk jamak dari kata tersebut, adalah sifat manusia yang berhubungan dengan pendidikan tinggi. Naila Farah, "DAKWAH REVOLUSIONER MUHAMMAD BIN ABD ALWAHHAB UNTUK PEMURNIAN AJARAN ISLAM," JURNAL YAQZHAN: Analisis Filsafat, Agama Dan Kemanusiaan 3, no. 1 (2017), https:// doi.org/10.24235/jy.v3i1.2037.

17 Karakter adalah aspek kepribadian seseorang yang secara langsung dipengaruhi oleh otak. Istilah "pendidikan karakter" diciptakan sebagai tanggapan atas kritik dan ketidakpuasan terhadap cara pendidikan moral yang telah dipraktikkan selama ini. Terlepas dari kenyataan bahwa mereka berbeda secara signifikan, tidak ada perbedaan yang signifikan antara keduanya. "GRAND DESAIN PENDIDIKAN KARAKTER GENERASI EMAS 2045," Jurnal Pendidikan Karakter, no. 1 (2013), https:/ / doi.org/10.21831/jpk.v0i1.1283. 
tindakan banyak orang Indonesia. Kondisi tersebut disinyalir bersumber dari apa yang dihasilkan dunia pendidikan. ${ }^{18}$

Demoralisasi disebabkan oleh fakta bahwa pembelajaran secara moral dan karakteristik membatasi teks dan tidak mempersiapkan siswa untuk hidup dalam kontradiksi. Ini bisa menjadi salah satu alasan pelatihan formal di sekolah/madrasah, karena pelatihan di Indonesia lebih mementingkan perkembangan intelektual atau kognitif, sedangkan aspek soft skill atau non-akademik belum dianggap sebagai elemen utama pendidikan moral.

Karena domain ketiga saling berhubungan, hasil belajar siswa tidak dapat dilihat hanya melalui lensa domain kognitif dan psikomotorik, seperti yang terjadi dalam praktik pendidikan kita. Sebaliknya, mereka harus dilihat melalui lensa hasil afektif., meskipun dengan berbagai tingkat kekuatan pemahaman. Berbagai temuan penelitian menunjukkan bahwa efektivitas kerja perusahaan berkaitan langsung dengan efektivitas ranah afektif. ${ }^{19}$

Nilai-nilai yang menentukan karakter dan budaya bangsa juga telah dimasukkan ke dalam kurikulum atau mata pelajaran di SD Negeri Brotonegaraan 2 Ponorogo yang merupakan rencana tertulis yang memuat ide dan konsep yang dikembangkan oleh pengembangan kurikulum. Kurikulum pendidikan dapat dianggap sebagai dokumen perencanaan yang mencakup tujuan yang ingin dicapai, materi dan pengalaman belajar yang harus diselesaikan siswa, strategi dan metode yang dapat dikembangkan, evaluasi yang dirancang untuk mengumpulkan data yang objektif, dan implementasi dari dokumen yang dirancang. dalam kehidupan nyata. Ada banyak komponen kurikulum yang berbeda yang saling berhubungan dan mempengaruhi satu sama lain; ini termasuk tujuan yang berfungsi sebagai arahan pendidikan, komponen pembelajaran pengalaman, komponen tujuan strategi, dan komponen evaluasi. Kurikulum berfungsi sebagai peta jalan pendidikan, membimbing siswa ke arah yang benar dan dengan tujuan yang jelas. ${ }^{20}$

Ketika kurikulum KBK dan KTSP diterapkan antara tahun 2004 dan 2008, otoritas guru lebih ditekankan dalam menentukan indikator, pengalaman belajar, dan urutan pembelajaran yang dapat membantu siswa memenuhi Standar Kompetensi dan Kompetensi Dasar pemerintah pusat. Pentingnya pendidikan agama (PAI) dan pendidikan kewarganegaraan telah diakui secara eksplisit, misalnya PAI yang berakhlak mulia atau PPKN, atau PAI yang berwawasan kepribadian. Hal ini akan memberikan kesempatan yang jauh lebih baik untuk meningkatkan moral siswa daripada yang diantisipasi sebelumnya jika mata pelajaran ini dapat diintegrasikan

18 Zubaedi, “Desain Pendidikan Karakter," Journal of Chemical Information and Modeling 53, no. 9 (2011).

${ }^{19}$ Muntholi'ah Muntholi'ah, "Ujian Nasional, Dulu, Kini Dan Yang Akan Datang: Tinjauan Normatif," Nadwa 7, no. 1 (2013), https://doi.org/10.21580/nw.2013.7.1.557.

20 Wina Sanjaya, Kurikulum Dan Pembelajaran: Teori Dan Praktik Pengembangan, KTSP Jakarta, Kencana Prenada Media Group, 2009. 
ke dalam pembelajaran nyata di sekolah/madrasah, dengan penekanan dan pendekatan yang kuat pada akhlak mulia, pengembangan karakter, dan pengembangan kepribadian. Namun, untuk memperkuat perubahan perilaku siswa yang menghasilkan nilai-nilai kehidupan, tidak hanya prestasi akademik, tetapi juga belajar untuk unggul dalam hidup, bukan belajar untuk unggul dalam hidup.

Desain kurikulum pendidikan karakter bukanlah desain kurikulum materi pelajaran yang akan diajarkan, melainkan desain proses pembiasaan perilaku moral pada siswa. Untuk mengajarkan nilai-nilai moral secara efektif, pendidik harus mengangkat pendidikan moral sampai pada titik di mana proses pendidikan menjadi proses pembentukan moral bagi peserta didik. Nilai-nilai moral dapat diajarkan sebagai mata pelajaran yang berdiri sendiri atau bersamaan dengan mata pelajaran lain. Bukan proses dimana pengetahuan moral diperoleh, tetapi proses dimana pengetahuan diberikan, adalah proses yang terintegrasi di sini.

Tujuan pendidikan karakter berprestasi adalah untuk menanamkan kecerdasan berupa pemikiran, penghayatan dalam bentuk sikap, dan pengalaman dalam bentuk perilaku yang selaras dengan nilai-nilai luhur yang menjadi jati dirinya. Pendidikan karakter tidak dapat direduksi menjadi transfer pengetahuan atau pelatihan keterampilan tertentu. ${ }^{21}$ Pendidikan karakter memerlukan suatu proses, misalnya pembiasaan atau pembudayaan di lingkungan sekolah/madrasah siswa, keluarga, masyarakat, dan lingkungan media massa.

\subsection{Pengembangan Pendidikan dan Budaya Karakter Bangsa Di Madrasah Ibtidaiyah Ma'arif Mayak Ponorogo}

Pola pertama, MI Ma'arif Mayak Tonatan Ponorogo telah mengembangkan 18 nilai karakter yang telah disepakati oleh kementerian pendidikan nasional Madrasah Ibtidaiyah Ma'arif Mayak Tonatan Ponorogo telah mengembangkan 18 nilai pendidikan dan budaya karakter bangsa, yaitu religius, jujur, toleransi, disiplin, kerja keras, kreatif, mandiri, demokratis, rasa ingin tahu, semangat kebangsaan, cinta tanah air, menghargai prestasi, bersahabat/komunikatif, cinta damai, gemar membaca, peduli lingkungan, peduli sosial, dan tanggung-jawab.

Pola kedua, MI Ma'arif Mayak Tonatan Ponorogo telah mengembangkan karakter at-tawassuth, at-tawazun, dan al-i'tidal. Di samping 18 nilai pendidikan karakter tersebut di atas, Madrasah Ibtidaiyah Ma'arif Mayak Tonatan Ponorogo juga mengembangkan nilai-nilai karakter yang disepakati oleh NU, nilai pendidikan aswaja yang meliputi tiga pilar utama, yaitu : at-tawassuth, at-tawazun, dan al-i'tidal.

Pertama, dalil at-tawassuth (menengah, moderat) aqli (argumen berdasarkan akal rasional) dan argumentasi naqli (argumen berdasarkan Al-Qur'an dan Hadits) sama-sama at-tawazun atau seimbang. Dalam kasus ketiga, tegak lurus al-I'tidal.

21 Zubaedi, “Desain Pendidikan Karakter.” 
Dalam Al-Qur'an Allah SWT berfirman yang artinya Wahai orang-orang yang beriman hendaklah kamu sekalian menjadi orang-orang yang tegak membela (kebenaran) karena Allah menjadi saksi (pengukur kebenaran) yang adil. Dan janganlah kebencian kamu pada suatu kaum menjadikan kamu berlaku tidak adil. Berbuat adillah karena keadilan itu lebih mendekatkan pada taqwa. Dan bertaqwalah kepada Allah, karena sesungguhnya Allah Maha Melihat apa yang kamu kerjakan. (QS al-Maidah: 8).

Pola Ketiga: MI Ma'arif Mayak Tonatan Ponorogo telah mengembangkan nilai karakter yang telah dikembangkan melalui 3 jalur, yaitu mapel, pengembangan diri dan budaya madrasah

Implementasi nilai-nilai karakter dan budaya bangsa tersebut di Madrasah Ibtidaiyah Ma'arif Mayak Tonatan Ponorogo tidak diajarkan tetepi diinternalisasikan dan dikembangkan di sekolah dan di dalam kelas melaui tiga jalur, yaitu kekuatan pembelajaran mata pelajaran, kegiatan pengembangan diri dan kegiatan budaya madrasah

Dalam pendidikan karakter di Madrasah Ibtidaiyah Ma'arif Mayak Tonatan Ponorogo, ada dua pendekatan: (1) menarik karakter sebagai mata pelajaran yang berbeda, seperti aqidah akhlak dan aswaja; dan (2) karakter yang ditanamkan pada setiap mata pelajaran. Pada titik waktu ini, telah ditetapkan bahwa pendekatan pertama lebih efektif daripada yang kedua. Salah satu penyebabnya adalah guru masih mengajarkan teori dan konsep serta belum memahami metrologi dan penerapannya secara menyeluruh dalam kehidupan nyata. Jika semuanya berjalan sesuai rencana, maka setiap proses pembelajaran akan mencakup unsur konsep (alam), teori (syare'at), metode (tharekat), dan aplikasi (ma'rifat). Pembelajaran guru akan lebih efektif dalam mendukung pendidikan karakter jika menerapkannya secara holistik, memasukkan konsep, teori, metodologi, dan aplikasi dari masing-masing bidang studi ke dalam pembelajarannya.

Dalam implementasinya diperlukan adanya (1) Pengabdian kepada Tuhan dan seluruh alam semesta beserta isinya; (2) akuntabilitas, disiplin, dan kemandirian; (3) integritas; (4) rasa hormat dan sopan santun; (5) kasih sayang, perhatian, dan kerjasama; (6) kepercayaan diri, kreativitas, dan ketekunan; dan (7) keadilan dan kepemimpinan; kebaikan dan kerendahan hati; toleransi, perdamaian, dan persatuan; dan pada Pendidikan di sekolah/madrasah harus mencakup kajian dan penerapan nilai-nilai kebangsaan yang melekat pada budayanya.. Upaya mengintegrasikan nilainilai kebangsaan ke dalam kegiatan pembelajaran dimungkinkan melalui tahapan perencanaan, pelaksanaan, dan evaluasi. Atas dasar kepercayaan yang telah lama dipegang bahwa anak-anak akan berkembang jika proses pembelajaran alami diikuti, tidak mungkin untuk membenarkan proses pembelajaran karakter yang terintegrasi. digunakan dalam konteks pembelajaran pengalaman yang bermakna dalam pengaturan yang bermakna. Dalam definisi yang paling dasar, pengajaran terpadu 
adalah konsep yang mengacu pada metode pembelajaran yang menyatukan berbagai bidang studi untuk memberikan pengalaman yang bermakna bagi pelajar. Mereka mengklaim bahwa pembelajaran terpadu bermanfaat karena memungkinkan siswa untuk mempertahankan konsep lebih efektif sementara juga membuat hubungan antara mereka dan konsep lain yang diperoleh melalui kesempatan untuk mempelajari tema atau peristiwa otentik (berbasis alam).

Dengan demikian, pendidikan terpadu memiliki ciri-ciri sebagai berikut: (1) berpusat pada peserta didik; (2) memberikan pengalaman langsung kepada siswa; (3) pemisahan bidang studi tidak sepenuhnya jelas; (4) menggabungkan konsep dari berbagai bidang studi ke dalam proses pembelajaran; (5) fleksibel; dan (6) hasil belajar dapat dikembangkan sesuai dengan minat dan kebutuhan siswa. ${ }^{22}$

Dimungkinkan untuk memasukkan pembelajaran ke dalam materi, pendekatan, dan metode yang digunakan dalam pengembangan model, serta untuk mengevaluasi model yang telah dikembangkan. Mengingat tidak semua materi cocok untuk semua karakter yang sedang dikembangkan, maka perlu untuk memilih dan menyelaraskan materi dengan karakter yang sedang dikembangkan. Sementara secara teoritis semua mata pelajaran secara teoritis dapat digunakan untuk mengembangkan semua karakter siswa, perlu diambil keputusan berdasarkan pendekatan materi yang akan dikembangkan agar tidak terjadi tumpang tindih dan tidak ada satu pun karakter yang akan dikembangkan yang terlewatkan.

Penanaman (penanaman), keteladanan (modelling, qudwah), fasilitasi (fasilitasi), dan pengembangan keterampilan adalah semua pendekatan dan metode (skill building). ${ }^{23}$ Ciri-ciri penanaman nilai (penanaman) sebagai berikut: (1) mengkomunikasikan keyakinan beserta alasannya; (2) memperlakukan orang lain dengan adil; (3) menghormati pandangan orang lain; (4) mengungkapkan keraguan dengan alasan dan rasa hormat; (5) tidak sepenuhnya mengendalikan lingkungan untuk meningkatkan kemungkinan penyampaian nilai-nilai yang baik; dan (6) menciptakan pengalaman nilai sosial dan emosional. Pendidikan karakter harus menghindari metode induktif yang tidak sesuai dengan penanaman.

Memberi teladan atau memberi contoh merupakan strategi yang sering digunakan dalam pendidikan karakter. Dua kondisi harus dipenuhi untuk menggunakan strategi ini. Untuk memulai, guru harus memberikan contoh positif bagi siswa dan anak-anaknya. Kedua, siswa harus meneladani orang-orang terkemuka yang mencontohkan kebajikan, seperti Nabi Muhammad. Cara guru menyelesaikan konflik secara adil, menghargai pendapat anak, dan sopan mengkritik orang lain merupakan perilaku wajar yang harus diteladani oleh anak.

22 Zubaedi.

23 Sean Lynch, "The Rationale for Selecting and Standardizing Iron Status Indicators," Geneva, World Health Organization, 2012. 
Metode penanaman dan keteladanan (al-qudwah) menunjukkan kepada siswa metode yang paling efektif untuk menyelesaikan berbagai masalah; orang akan memproses, meniru, dan memodelkan metode ini. Seseorang yang menggunakan metode pembiasaan akan menunjukkan tingkat komitmen yang tinggi. Pembiasaan dalam penanaman akhlak merupakan tahap kritis yang harus mengiringi perkembangan setiap mata pelajaran. Mengajarkan akhlak tanpa mengembangkan kebiasaan-kebiasaan yang diperlukan sama saja dengan menabur benih di tengah lautan, karena akhlak bukanlah sekedar pengetahuan, melainkan pembiasaan akhlak. Fasilitasi mengajarkan siswa bagaimana menyelesaikan masalah ini. Kegiatan yang dilakukan siswa saat menerapkan metode fasilitasi memiliki efek positif pada perkembangan mereka.

Pendidikan moral akan lebih efektif jika disajikan secara visual, seperti melalui film, sehingga siswa tidak hanya dapat menangkap makna pesan verbal mono-pesan, tetapi juga makna pesan visual multi-pesan, serta keterkaitan antara pesan-pesan verbal. gambar dan peristiwa dalam alur cerita. ${ }^{24}$ Misalnya menyampaikan pesan bahwa narkoba harus dihindarkan, maka kesan orang yang dipenjara karena menjadi korban narkoba jauh lebih signifikan daripada yang disampaikan secara lisan, melalui metode membaca. Namun, jika Anda ingin mengeksplorasi tingkat akseptabilitasnya, Anda dapat melanjutkan metode meditasi Anda setelah cerita dalam film yang ditayangkan dikondisikan dengan baik.

Setiap orang memiliki kombinasi unik dari kecerdasan, kemampuan, dan keterampilan. Mereka juga memiliki temperamen dan watak yang unik. Orang dengan sikap tenang yang mudah berpikir atau bernalar jarang terjadi. Beberapa dari mereka mudah dijangkau hanya dengan menghadapi mereka ketika mereka salah, sedangkan yang lain tidak akan berubah kecuali mereka melebarkan mata, meskipun menggunakan tangisan, ancaman, dan kekerasan fisik. Hukuman adalah metode pendidikan, tetapi guru harus menghindari menggunakannya sebelum mencoba metode pengajaran lain terlebih dahulu. Metode hukuman bisa di laksanakan pada materi ke rabbanian karena untuk memberikan efek jera apabila melanggarrnya dan untuk melatih kekhusukan peserta didik. ${ }^{2526}$

24 In the world of education, especially those related to learning, the role of learning media is very strong. Albert Meharabien found the role of media in conveying information, with the three V. Verbal formula; can only add 7\%, Vowels; can deliver 38\%, if accompanied by varied voice colors and the right intonation, while visual; can reach an effectiveness rate of up to 55\%. Humans have a more optimal ability to capture meaning, through visual impressions compared to verbal and vocal ones. Yasinta Mahendra, "Pendidikan Karakter Di Sekolah [CHARACTER EDUCATION IN SCHOOL]," SEMINAR NASIONAL PAGELARAN PENDIDIKAN DASAR NASIONAL (PPDN) 1, no. 1 (2019).

${ }^{25}$ Al-Nahlawi, Ushul Al-Tarbiyah Al-Islāmiyah Wa Asālibuhā Fi Al-Bait Wa Al-Madrasah Wa Al-Mujtama' (Damaskus: Dar al-Fikr, 2007).

${ }^{26}$ Kitāb Al-Akhlāq (Cairo: Dar al-kutub al-Mishriyah, 1929). 


\subsection{Pengembangan Pendidikan dan Budaya Karakter Bangsa Di Pesantren Darul Falah Sukorejo Ponorogo}

Pola pertama, Pondok Pesantren Darul Falah Sukorejo Ponorogo telah mengembangkan 18 nilai karakter yang telah disepakati oleh Kementerian Pendidikan Nasional. Religius, jujur, toleransi, disiplin, kerja keras, kreatif, mandiri, demokratis, rasa ingin tahu, semangat kebangsaan, cinta tanah air, menghargai prestasi, bersahabat/komunikatif, cinta damai, gemar membaca, tanggung jawab lingkungan dan sosial adalah beberapa di antaranya merupakan nilai-nilai yang telah dikembangkan di Madrasah Ibtidaiyah Ma'arif Mayak Tonatan Ponorogo, serta nilainilai lain seperti toleransi, kejujuran dan toleransi.

Pola kedua, Pondok Pesantren Darul Falah Sukorejo Ponorogo telah mengembangkan karakter at-tawassuth, at-tawazun, dan al-i'tidal. Di samping 18 nilai pendidikan karakter tersebut di atas, Madrasah Ibtidaiyah Ma'arif Mayak Tonatan Ponorogo juga mengembangkan nilai-nilai karakter yang disepakati oleh NU, nilai pendidikan aswaja yang meliputi tiga pilar utama, yaitu: at-tawassuth, at-tawazun, dan al-i'tidal.

Pola ketiga, Pondok Pesantren Darul Falah Sukorejo Ponorogo telah mengembangkan karakter pancajiwa pesantren Pesantren Darul Falah Sukorejo Ponorogo di samping mengembangkan 18 nilai pendidikan karakter dan 3 nilai karakter NU, juga mengembangkan nilai-nilai karakter memalui penanaman pancajiwa pesantren, yaitu keikhlasan, kesederhanaan, mandiri, persaudaraan dan kebebasan.

Pola keempat, Pondok Pesantren Darul Falah Sukorejo Ponorogo telah mengembangkan karakter melalui lima jalur. Implementasi pendidikan karakter dalam proses pembelajaran dengan lima cara., yaitu (1) Dikembangkan melalui mata pelajaran kepesantren-an; (2) Mengintegrasikan ke dalam setiap mata pelajaran dan langkahlangkah pembelajarannya; (3)Mengintegrasikan ke dalam berbagai peraturan serta kebiasaan yang di praktekkan di pondok pesantren Darul Falah Sukorejo Ponorogo.; (4) Dikembangkan melalui keteladanan dari penanggung jawab pendidikan.; (5) Menciptakan dan mengondisikan kebiasaan (sunnah-sunnah kepesantrenan)

\section{KESIMPULAN}

Pendidikan karakter merupakan suatu keharusan untuk diterapkan di Indonesia. Pendidikan karakter bertujuan untuk membentuk bangsa yang tangguh, berdaya saing, berakhlak mulia, bermoral, toleran, gotong royong, berjiwa iptek, dan dinamis, yang dijiwai oleh Tuhan Yang Maha Esa yang beriman dan bertakwa berdasarkan Pancasila. Seluruh lembaga pendidikan, termasuk SD Negeri Brotonegaraan 2 Ponorogo, MI Ma'arif Mayak Ponorogo, dan Pondok Pesantren Darul Falah Sukorejo 
Ponrogo, harus mendukung pelaksanaan pendidikan karakter, karena juga sebagai lembaga pembinaan akhlak dan dakwah, selain sebagai lembaga pendidikan. institusi.

Satu hal yang perlu diperhatikan dari temuan penelitian ini adalah jalur KBM, jalur budaya sekolah dan jalur ekstrakurikuler tidak cukup dalam pengembangan pendidikan budaya dan karakter bangsa. Oleh karena itu jalur pembiasaan dalam kehidupan sehari-hari di rumah adalah sebuah keniscayaan, sebagaimana pola berikut.

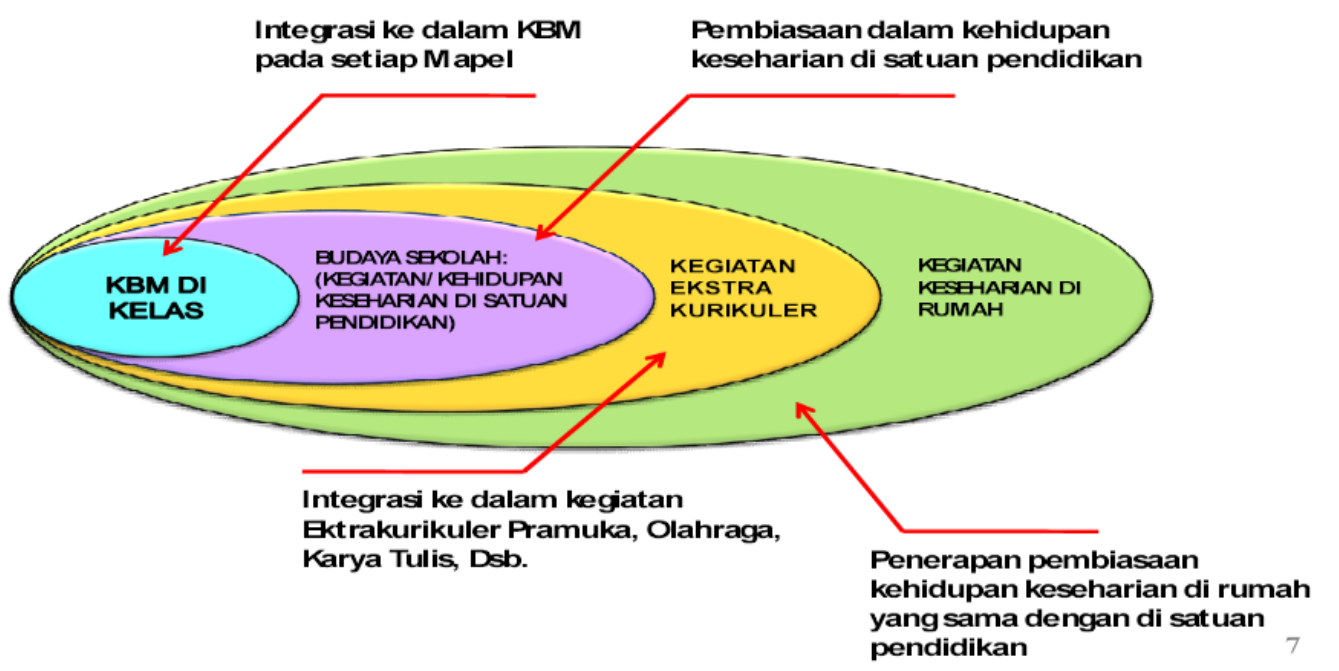

Ada beberapa saran yang perlu diperhatikan oleh pihak-pihak terkait berikut. Pertama, Pimpinan Pondok Pesantren. hasil penelitian ini dijadikan rujukan bagi pimpinan pondok pesantren bahwa pendidikan karakter di pesantren dikembangkan tidak hanya berdasarkan pedoman yang ditetapkan oleh pemerintah, tetapi lebih dari itu karakter dikembangkan berdasarkan budaya pesantren yang kental dengan nilainilai karakter. Kedua, Kepala Sekolah. Sebagai pemegang kebijakan tertinggi di sekolah, kepala sekolah harus mengawal pendidikan karakter dan budaya bangsa dengan ketat, terus-menerus dan berkesinambungan. Ketiga, Guru . Sebagai pengajar gawang paling depan dalam pendidikan karakter, guru harus menjadi panutan dan suri tauladan, sebagaimana yang ditulis Kihajar Dewantoro "Ing Ngarso Sung Tulodho, Ing Madyo Mangun Karso, Tut Wuri Handayani". Keempat, Orang Tua. Sebagai penanggungjawab pertama dan utama dalam melaksanakan pendidikan karakter dan budaya bangsa, orang tua harus selala mengawal nilai-nilai karakter putra-putrinya dengan cara lahiriyah dan bathiniyah.

\section{REFERENSI}

Al-Nahlawi. Ushul Al-Tarbiyah Al-Islāmiyah Wa Asālibuhā Fi Al-Bait Wa Al-Madrasah Wa Al-Mujtama'. Damaskus: Dar al-Fikr, 2007. 
Bogdan, Robert C., and Sari Knopp Biklen. "Characteristics of Qualitative Research." In Qualitative Research for Education: An Introduction to Theory and Methods, 2003.

Brooks, Helen, Penny Bee, and Anne Rogers. "Introduction to Qualitative Research Methods." In A Research Handbook for Patient and Public Involvement Researchers, 2019. https:/ / doi.org/10.7765/9781526136527.00012.

Farah, Naila. "DAKWAH REVOLUSIONER MUHAMMAD BIN ABD AL-WAHHAB UNTUK PEMURNIAN AJARAN ISLAM." JURNAL YAQZHAN: Analisis Filsafat, Agama Dan Kemanusiaan 3, no. 1 (2017). https://doi.org/10.24235/jy.v3i1.2037.

"GRAND DESAIN PENDIDIKAN KARAKTER GENERASI EMAS 2045." Jurnal Pendidikan Karakter, no. 1 (2013). https:/ / doi.org/10.21831/jpk.v0i1.1283.

Kementerian Pendidikan dan Kebudayaan. "Kementerian Pendidikan Dan Kebudayaan." Http://Kemdikbud.Go.Id/1969010819, no. 0281 (2017).

Kementerian Pendidikan Nasional. UU Nomor 20 Tahun 2003 tentang Sistem Pendidikan Nasional. Undang-Undang Republik Indonesia Nomor 20 Tahun 2003 Tentang Sistem Pendidikan Nasional Dengan Rahmat Tuhan Yang Maha Esa Presiden Republik Indonesia, issued 2003.

Kitāb Al-Akhlāq. Cairo: Dar al-kutub al-Mishriyah, 1929.

Lofland, John, David Snow, Leon Anderson, and Lofland Lyn. “Analyzing Social Settings: A Guide to Qualitative Observation and Analysis (4th Ed.)." Analyzing Social Settings: A Guide to Qualitative Observation and Analysis (4th Ed.), 2006.

Lynch, Sean. "The Rationale for Selecting and Standardizing Iron Status Indicators." Geneva, World Health Organization, 2012.

Mahendra, Yasinta. "Pendidikan Karakter Di Sekolah [CHARACTER EDUCATION IN SCHOOL]." SEMINAR NASIONAL PAGELARAN PENDIDIKAN DASAR NASIONAL (PPDN) 1, no. 1 (2019).

Miles, Matthew B, and Michael A. Huberman. Analisis Data Kualitatif: Buku Sumber Tentang Metode-Metode Baru. UI Press, 2012.

Muntholi'ah, Muntholi'ah. “Ujian Nasional, Dulu, Kini Dan Yang Akan Datang: Tinjauan Normatif." Nadwa 7, no. 1 (2013). https://doi.org/10.21580/nw.2013.7.1.557.

Patton, Michael Q., Egon G. Guba, and Yvonna S. Lincoln. "Effective Evaluation: Improving the Usefulness of Evaluation Results Through Responsive and Naturalistic Approaches." The Journal of Higher Education 54, no. 3 (1983). https:/ / doi.org/10.2307/1981810.

Sanjaya, Wina. Kurikulum Dan Pembelajaran: Teori Dan Praktik Pengembangan, KTSP Jakarta. Kencana Prenada Media Group, 2009.

Wahid, Salahudin. "PENDIDIKAN KARAKTER BERBASIS PESANTREN." TARBAWI 3, no. 1 (2018). https://doi.org/10.36781/tarbawi.v3i1.2961.

Zubaedi. "Desain Pendidikan Karakter." Journal of Chemical Information and Modeling 53, no. 9 (2011).

(C) 2021 by the authors. Submitted for possible open access publication under the terms and conditions of the Creative Commons Attribution-NonCommercial 4.0 International License (CC BY NC) license (https:// creativecommons.org/licenses/by-nc/4.0/). 